\title{
INTRODUCTION: POSSIBILITIES, FUTURES, AND QUEER WORLD-MAKING IN CHILD AND YOUTH CARE
}

\author{
Wolfgang Vachon and Mattie Walker
}

\begin{abstract}
In this introduction, the authors situate this special issue within the current sociopolitical contexts of child and youth care (CYC) and offer potentialities through "queering CYC". They consider how CYC might be analyzed through a queered lens, outline ways CYC has, and has not, taken up queer theory, and imagine what a queered CYC might (un)become. The authors provide context for this issue and invite queer generosity in reading how queering can be in conversation with CYC.
\end{abstract}

Keywords: queer CYC, generosity, queering care, sexuality in CYC

Wolfgang Vachon (corresponding author) is a professor of Child and Youth Care at Humber College, 3170 Lake Shore Blvd. W., Etobicoke, ON M8V 3 X8.

Email: Wolfgang.Vachon@,Humber.ca

Mattie Walker MA is a graduate of the School of Child and Youth Care and a current $\mathrm{PhD}$ student in the Social Dimensions of Health Program at the University of Victoria, 3800 Finnerty Rd., Victoria, BC V8W 2Y2. Email: mattiew@uvic.ca 
This is the first special issue in any child and youth care (CYC) journal that explicitly seeks to "queer child and youth care". The idea for this special issue came out of a conversation sparked by Vachon's (2020) call for our field to consider what queering care in CYC might do and Walker's (this issue) exploration of how queer and trans topics are currently being discussed in the CYC literature. Our editorial committee, made up of four individuals involved in various forms of CYC practice (current and past practitioners) and academia (students, mid-career, moving to retirement), was brought together through a shared wondering, "Where is the queerness of CYC?"

Our conversations started in the spring of 2020, in the early months of the COVID-19 global health crisis. Coming together over Zoom video, from the traditional territories of Songhees, Esquimalt, and WSÁNEĆ peoples, the Huron-Wendat and Petun First Nations, the Anishinaabe, and the Six Nations of the Haudenosaunee, as well as the Mississaugas of the Credit First Nation

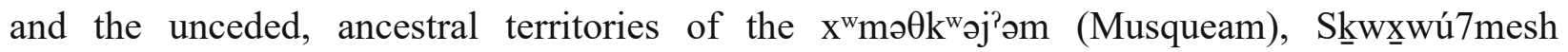
(Squamish), and səlilwəta?1 (Tsleil Waututh) Nations. We started our conversation with the backdrop of international movements calling for racial justice, demanding accountability for police brutality, and pushing back against hundreds of years of White supremacy. Starting in January 2020, Indigenous activists from the Wet'suwet'en nation catalyzed action across Canada in response to the Coastal GasLink Pipeline, and Black Lives Matter activists protested the murders of George Floyd and Breonna Taylor. These actions renewed ongoing social justice conversations and small changes began happening across Turtle Island, which continued into 2021 with recognition and responses to anti-Asian racism, the "discoveries" of buried bodies on the land of former residential schools, and the ongoing systemic discrimination in many realms including health care and child welfare.

These movements draw attention, once again, to the ongoing injustices faced by racialized communities and show how policy, policing, and governance - steeped as they are in White supremacy - continue the colonial project of normalization. Last year, 2020, was the deadliest year on record for trans people, with over 40 reported murders of trans people in North America and at least 350 trans people killed worldwide, continuing a trend of annual increases (Clifton, 2020; Sonoma, 2021). We live in a time that calls on those in positions of privilege and power to acknowledge the ongoing injustices faced by many people, and a demand for communities and individuals to do better in our own lives. Within this context, our editorial group came together to wonder, with the desperate need for social change in our current political climate, what might queering CYC do for us as a field?

It is distressing, although perhaps not surprising, that this is the first explicitly queer-themed special issue in CYC. Much of the CYC agenda historically has been a project of normalization. As many of the papers in this special issue point out, this is still prevalent in many contexts throughout $\mathrm{CYC}$, including practice, literature, education, and research (e.g., see Zaman and Anderson-Nathe's discussion in this issue of the potential for using queer theory as an analytic to 
deconstruct developmentalism in the context of (YC). There have been increasing calls over the past decade and a half to confront this history, and over the last several years this has moved from call, to demand, to accountability, with action being taken that shifts how we think of and enact CYC (along with the predictable pushback). In this we are beginning to see training for practitioners and educators that is focused on anti-Black and anti-Indigenous racism, challenges to entrenched child welfare practices, conscious and active hiring practices in post-secondary CYC programs, changes in publication patterns, and increasing numbers of conversations within and across CYC demographics. Many of these conversations are focused on racial politics (Amponsah \& Stephen, 2020; Batasar-Johnie, 2017; Daniel, 2018), Indigeneity and decolonizing practices (de Finney et al, 2020; Ineese-Nash, 2020), White supremacy and Whiteness in the field of CYC (Hillman et al., 2020; MacKenzie, 2019; Skott-Myhre et al., 2020), and the legacy of these dynamics in CYC (Hyder et al., 2019; Munroe, 2016). This has been accompanied by discussions regarding ability and disability (Erlich, 2019; Marshall, 2019), misogyny, and who has been setting the agenda of CYC ideas over the past several decades, although few of these later conversations have made it into the formal literature.

We sit uncomfortably within these contexts, as a White editorial board with our own intersecting identities and positionalities, wondering how discussions of queering $\mathrm{CYC}$ might connect with and continue the conversations about decolonizing CYC, addressing racial injustices, and acknowledging and holding space for the work of Black, Indigenous, and People of Colour (BIPOC), and Queer, Trans, BIPOC (QTBIPOC) practitioners and scholars? We also recognize, from our various positionalities, that bringing together a special issue on queering CYC is a risk, but from our various standpoints, we have decided we can afford this risk and leverage our perspectives to push back into the CYC field by presenting questions, considerations, and critiques for a field that has historically aligned itself with normalization. Muñoz (2019) offered that queerness is "an insistence on potentiality" and the possibility for another world (p. 1). With this in mind, we wonder, in queering CYC, what possibilities emerge for pushing back against a history of normalization, for challenging care that is harmful (de Finney et al., 2011), and for making visible the individuals and communities that have been erased and ignored from our CYC discourse, practice, research, and pedagogy.

\section{Embodied CYC}

Several of the writers in this special issue point out that the visible body reveals much about the person inhabiting the body — and those who interact with it (see, e.g., the articles by Gemar and by Longoria). The body becomes a locus for homophobia, transphobia, racism, ableism, misogyny, colonialism, and other forms of supremacy. The intersections of race and queerness, as revealed by QTBIPOC and two-spirit writers (Belcourt, 2020; Johnson \& Rivera-Severa, 2016; McCready, 2013; Pico, 2019; Puar, 2017; Simpson, 2020; Whitehead, 2018), make possible an understanding of heterosexism, transphobia, and binary gender systems "as manifestations and tools of colonialism and genocide" (Driskell, 2016, p. 25). These QTBIPOC and Two-Spirit critiques draw attention to the ways in which embodied experiences of intersecting identities 
position individuals and communities in importantly different perspectives. The practice of positioning as constitutive of queer theory (or queering theory) can be understood through Ahmed's (2006) discussion of queer as an orientation, as articulated in Queer Phenomenology: not just a sexual orientation, but an orientation to how bodies take up space, are oriented towards or away from certain ideas, and are aligned or "out of line" with what is expected. We wonder, if $\mathrm{CYC}$ had not been forced into conversations about identity, politics, and theory previously, would this special issue exist?

In $\mathrm{CYC}$, we see few writers, educators, or public figures who are "out" or who centre their queerness in their writing and work. At the same time, we recognize that there are several such CYC practitioners (CYCPs), and we are immensely grateful for those leaders in the community. Unlike race and many forms of disability, one may be able to hide, or deemphasize, one's sexual and affectional orientation or gender identity, and given the legacy of $\mathrm{CYC}$, it may be safer or more comfortable to not focus on that aspect of who we are. While this may be a privilege at times, it also acts as a powerful force in invisibilizing, and consequently erasing, queer and trans individuals within CYC. We know there are many practitioners who are lesbian, gay, bi, or twospirit, or are trans, gender-queer, non-binary, or otherwise not cis-gender, working directly with young people; however, their experiences, voices, and practices have not always had a visible presence within our field.

In putting this special issue together, we recognize the important intersecting ways that power, privilege, and oppression make themselves known in the work of writing and researching. While many queer, trans, and, importantly, QTBIPOC CYCPs are a part of the field, they may not be compensated for time put towards writing, researching, and publishing. This highlights how privilege enacts which voices are heard and which bodies are seen in academia - and consequently, which perspectives are presented in CYC education and training. In editing this issue, we were reminded of the economics of publishing, of how relationships serve knowledge production, of academic racism, and of the reality that few QTBIPOC CYCPs have the time and resources to take on unpaid writing for scholarly journals. All of these elements perpetuate privilege. Only a limited number of the QTBIPOC people we reached out to for articles were able to contribute. In this, we see the complex politics of wanting to change who authors CYC literature, and the reality that academic writing is generally unpaid labour that only those with the time, resources, financial means, or institutional support can pursue. This is part of the reason that the literature of CYC has been written predominantly by White, able-bodied, heterosexual people tied to the academy. The institutional (and societal) structures that allow only certain people the time to write, to edit, and to peer-review are exploitative.

We wonder about these dynamics when we consider the submissions received. Most of them are from students, and the few that are not are from people employed in the academy, as are the editors. In short, everyone who worked on this project is receiving some sort of "compensation". Some are paid within their academic positions, which entail expectations of publishing; some will receive publication credits on $\mathrm{CVs}$, which will be taken into consideration for the next steps in 
their career trajectories, be that further schooling, academic positions, tenure, or recognition for contributions made to the field as they look for work. The privilege that allowed us to be the editors of this issue needs to be acknowledged and to continue to be addressed. There are increasing demands being placed on QTBIPOC CYCPs to write, to educate, to present, to teach on issues and topics that directly impact them, frequently without any or only minimal compensation. This is yet another form of racism, privilege, and supremacy revealing itself: asking those who have been most impacted by racism or other forms of discrimination to teach those who are benefiting from it, sometimes in hostile environments, and frequently without adequate compensation.

\section{No Normo}

Due to the limited number of texts within CYC written through queer-coloured glasses, it is worth taking a moment to lay out what we mean by queer and how we understand CYC. Queering, as we are using it in this special issue, is a process that involves analyzing a given topic through a queer theory lens. Broadly speaking, in this case, the topic is CYC. Queer, as you will see throughout this special issue, is a contested and amorphous term. Almost 20 years ago Nikki Sullivan (2003) wrote:

While Queer Theory may now be recognized by many as an academic discipline, it nevertheless continues to struggle against the straightjacketing [sic] effects of institutionalization, to resist closure and remain in the process of ambiguous (un)becoming ... queer is a discipline that refuses to be disciplined. (p. V)

This (un)becoming continues and recent forays into queer theory, trans theory, and queer methodologies highlight the ongoing contestation in the field (Barker \& Scheele, 2016; Ghaziani \& Brim, 2019; Keegan, 2020). The term queer comes from the German word quer, whose contemporary meaning is "to cross" (Heckert, 2010, p. 42), taking up the idea of bridging, inbetweenness, and crossing of boundaries, stabilities, and knowledges. Queer theory resists definition because just as it understands sexuality, gender, and identity as "a discursive social construction, fluid, plural, and continually negotiated" (Chandler \& Munday, 2011), queer theory also challenges the notion of a fixed, core identity. This challenging does not stop at identity, however: "for many, 'queer' refers to more than just sexuality and gender. Rather, it refers to a position of dissent and critique against norms" (Ball, 2016, p. 36). Part of queer theory's distinctive semantic clout and political efficacy comes from what Jagose (1996) articulated as its resistance to definition and "the way in which it refuses to stake its claim" (p. 1).

We can see the possibilities these approaches present when thinking of research, for example (Ghaziani \& Brim, 2019). As Mayo (2017) noted, there continue to be complications in "how we each define, study, and theorize sexuality, gender, gender identity, and other intersecting categories of subjectivity like age, race, class, ethnicity" (p. 530). Identity categories are constantly being stabilized and destabilized across different approaches to research methodologies, including both quantitative and qualitative projects (Mayo, 2017). Taking up a queer approach, as well as acknowledging the work being done in queer communities as research, may offer researchers 
different spaces and capacities to think beyond the limitations of identity categories, while holding complexity as a tool (Lather, 2009) that can push researchers to consider new practices.

Thinking beyond identity categories opens up possibilities while causing disquieting ruptures. Such complexity challenges some of what we wrote above regarding identity, and also presents ways to consider the historical focus of CYC, as we will discuss below. Trans theory can be helpful in navigating the dynamics of identity, recognizing "how transgender studies departs from queer theory's deconstructive mode to place high value on constative self-knowledge, or how this value developed as a political response to the specific medical narratology of transgender (i.e., transsexual) life" (Keegan, 2020, p. 350). Thus, we see trans theory centering, rather than collapsing identity (Ellison et al. 2017; Stryker \& Bettcher, 2016). Much of this is in response to queer theory's cisgenderism and Whiteness, where identity deconstruction may be a privilege granted more readily to some bodies than others. In this issue, we hold space to critique identity, and understand the necessity of constative self-knowledge and people's enactments of self, including identity.

The word "queer" has carried multiple, at times hurtful, meanings. In the 1980s and 1990s, during the early days of HIV/AIDS, LGBT activists started to "reclaim" the word queer and invert the meaning from one of denigration to one of liberation. Groups such as Queer Nation ${ }^{1}$ and ACT $\mathrm{UP}^{2}$ refused to wait patiently as people died, casting off calls for "respectability" in their resistance. Queer activists raised money, staged die-ins at churches, educated the public, invaded pharmaceutical companies, mourned the dead, and covered streets in red paint demanding access to drugs, to health care, to being recognized; activists engaged in what David Román (1998) called acts of intervention: the fundraiser, the protest, the memorial. This resistance grew from several decades of lesbian and gay activism, including the now famous Stonewall riots (Duberman, 1993), which were primarily led by racialized trans folx alongside gay cis men who were fed up with police harassment.

Queer theory drew on these activist roots and developed from a theoretical lineage of existentialism, feminism, Black feminist \& POC critiques of feminism, sex and sexuality discourse, deconstructionism, intersectionality, and post-structuralism (Barker \& Scheele, 2016). Queer work continues to draw from critical theories as it responds to the ever-changing landscapes of life across the globe, and "is constantly troubling what we take for granted, and constantly refusing what is taken as solid" (Ball, 2016, p. 46). Alexander (2018) understood queer theory as:

engaged in an active process of contesting scholarship and politics, contesting categories, contesting identity, contesting liberalism, contesting truth, contesting history, and contesting subjectivity. In its most idealist and liberatory impulse, queer theory pivots on the following logics. Queer is used not only as a gendered

${ }^{1}$ https://queernationny.org/history

${ }^{2}$ https://actupny.com/contact/ 
International Journal of Child, Youth and Family Studies (2021) 12(3/4): 1-22

identity location but also as resistance to orthodoxy - expounding, elaborating, and promoting alternative ways of being, knowing, and narrating experience. (p. 278)

Within the idea of queer, we challenge and question boundaries in a way that offers a language for holding space full of complexity within the contexts of CYC. Queer theory is about thinking, approaching, and negotiating knowledges. As Heckert (2010) stated, "theory is a battlefield" (p. 42 ), and it is on this battlefield that we may contend with ideas that help us to grasp the world that we find ourselves a part of, "a way to conceive and to change our lives" (May, 2005, p. 517).

One might think of queer as noun and verb, with the noun signifying what something or someone is (while simultaneously rejecting categorization) and the verb signifying what someone does. Being queer is a way of understanding and experiencing one's desire, identity, sexuality, theory, and politics (Vachon, 2020). Doing queer is bringing a set of ideas, approaches, and perspectives to a topic: to queer something is to do something (Sullivan, 2003). This special issue contains all of these ideas, some explicitly and some less obviously. We invite you to consider these elements as you read through the rest of this introduction and the ensuing articles. The queer shows up in many ways.

\section{Child and Youth Care Theory}

CYC started from different theoretical orientations, agendas, and positions than those that animate queer theory. Rather than a field of contestation and refusal, CYC was born of alignment and acceptance. CYC emerged, and continues to emerge, from multiple intersecting and complementary theoretical lineages. White (2015) situated CYC as coming "out of a Euro-western, liberal humanist tradition [which] has been strongly influenced by colonial logic and the ideals of the Enlightenment" (p. 501). For Skott-Myhre \& Skott-Myhre (2012), “One of the central theories that define the field of child and youth care is that of developmental psychology" (p. 172). Zaman and Anderson-Nathe (this issue) critique developmental frames, asking how does one queer developmentalism? Kouri (2014) observed that the "field, inclusive of practice and academic domains, is generally concentrated on direct, caring, and holistic therapeutic relationships with children, youth, and families informed by developmental perspectives, systems theory, and a strengths-based approach" (p. 1). To this list, he added "self ... as having a central place in CYC theory and practice" (p. 1). Stuart (2013) in her book Foundations of Child and Youth Care wrote, "the primary influence on the profession is psychoanalytic theory, with some moderation by humanist theory, symbolic interactionism, and behaviourism" (p. 34).

CYC has always been informed by theory, although this has not always been acknowledged. For example, Garfat (2012) drew extensively upon phenomenology, from which he has developed a whole approach to working with children and youth based upon "moments" and "experience", yet little of his work outside of his $\mathrm{PhD}$ dissertation mentions phenomenology. CYC presents itself primarily as practice-based, with a literature that clearly situates $\mathrm{CYC}$ as a way of doing: "Child and Youth Care practice is based on helping people think about and live their life differently, as 
they are living it... It is a focused, timely, practical and, above all, immediately responsive form of caring" (Garfat et al., 2018, p. 11). Anglin (2001) wrote of five characteristics that differentiate CYC from other helping professions:

Child and youth care...

- is primarily focused on ... growth and development ...

- is concerned with the totality of a child's functioning ...

- has developed a model of social competence rather than a pathology-based orientation to child development ...

- is based on (but not restricted to) direct, day to day work with children and youth in their environment ...

- involves the development of therapeutic relationships. (para. 4-8)

CYC has long seen itself as a field that is about doing, being with, and working in "the lifespace", utilizing an approach that is based on "moments" in the "co-created space" between a CYCP and a child, youth, or family member (Garfat et al., 2018).

More recently people have begun questioning this seemingly apolitical framing of CYC through reflecting on their experiences as practitioners (Batasar-Johnie, 2017; Hillman et al., 2020; Munroe, 2016) and as system-involved young people (Cherry \& Vachon, 2020; Chung, 2017; see also the audio-drama "Tuning Into $\mathrm{CYC}^{\prime 3}$ ). This has led to asking what may be revealed about the CYC project through utilizing different analytical tools to consider what CYC does, and what it could be. de Finney et al. (2012) bring decolonial and Indigenous theory to both practice and thinking in $\mathrm{CYC}$, challenging many of the governing principles they see embedded within the field. Little (2011) is one of the first authors to invoke the need for queer theory (among other critical lenses) in CYC, writing:

For my training in CYC, I had to look elsewhere to queer heteronormative perspectives ... I needed a language outside CYC to speak to relational interaction and meaning making in a manner that acknowledged their complexity ... and I needed a critical race perspective that transcended a multicultural, singular discourse diversity lens. (p. 12)

Fortunately, we are now starting to see critical race perspectives within $\mathrm{CYC}$, and what is being laid bare reveals what many racialized practitioners, students, and educators have known for many years: racism, colonialism, ableism, and Whiteness infuse the CYC project. Amponsah and Stephen (2020), writing about the concept of "ally" in CYC, made explicit that:

White racial experience is the lens through which possibilities and limitations for different social relations are discussed and acted upon. This approach normalizes

${ }^{3}$ https://tuningintocyc.com/ 
International Journal of Child, Youth and Family Studies (2021) 12(3/4): 1-22

Whiteness as the entry point into goodness, understanding, and change, and poses many challenges for the field of child and youth work by contributing to the maintenance of a stagnant space of practice amidst rigid concepts of care. One example of such an outcome is the depoliticized and dehistoricized content that is taught in child and youth care curriculums, which ignores the importance of historically constituted sociopolitical realities. (pp. 7-8)

Queering CYC requires looking at where we come from and asking where we want to go. As August A. suggests in this issue, critically querying the implications of history can "(re)affirm the possibilities for queer and trans youth in the future". For Anderson-Nathe (2019a), the vision of a queered CYC results in a "transformed practice in all the settings and contexts in which CYCs work" (p. 158). As you read this special issue, you may note that many, if not all, of the authors agree with Anderson-Nathe.

Within this focus on "how you are; who you are; when you do; what you do" (Garfat \& Fulcher, 2012 , p. 1) it has been noted that written theory has at times been perceived as extraneous or unnecessary to CYC practice (Little, 2011). While this may be the perception of some, Amponsah and Stephen (2020) have pointed out that ignoring the theoretical underpinnings of the field allows formative theory to go unexamined, and obfuscates the disciplining work it does. From the pragmatic to the ideational and the therapeutic to the systemic, CYC draws upon multiple theoretical and practice constructs to serve (or not) children, youth, families, and communities.

While there have been accusations of an atheoretical, even antitheoretical, bent to CYC (de Finney et al., 2012), it is not so much that CYC is atheoretical, but rather that the theory it rests on sees itself as the norm. As the above very brief lineage tracing suggests, there are numerous tenets informing thinking, practice, writing, and education. We understand these tenets as forming a normative-orienting alignment. Despite CYC originating from normative epistemological roots, increasing numbers of practitioners, writers, researchers, and educators now challenge this historical intellectual orientation and work with diverse ideas to "develop" and rediscipline the corpus of knowledge. That is to say, CYC has clear and articulated theoretical foundations that inform practice, pedagogy, policy, and research; however, these are privileged and normalized positions that locate themselves as the unquestioned norm. At the same time, the field constantly brings in new ideas when they are attractive to practitioners or pedagogues. Rather than styling CYC as atheoretical, it might be more accurate to recognize CYCs Western colonial roots, and then ask if CYC is aligned with an expansionist project of "discovering" and "collecting" theories and practices, with the intention of redisciplining them into "the field". Through this reading, CYC can be understood as seeking out and then homogenizing and absorbing the other into our agendas, adopting theories and seeking to discipline them through a Western, developmental lens; thereby cramming different ontologies into the same normalizing practices. Such an approach would not be transdisciplinary; rather, it would be a form of neocolonial disciplining, of aligning. If this is indeed the case, we can reread the atheoretical indictments that have been raised as a resistance to the invisibilizing of the logics informing CYC and as a call to acknowledge our lineage. 
International Journal of Child, Youth and Family Studies (2021) 12(3/4): 1-22

\section{Queer Generosity}

We sought to queer our process from the beginning. In crafting our call for submissions, we collaborated on articulating an invitation to bring queerness into CYC, well aware that we were venturing into unfamiliar worlds for our CYC field. We sought to centre care by considering how we as editors would engage with authors. Early on we decided to offer authors an open review process, asking if they wanted to know who reviewed their manuscripts. We were also intentional, when inviting reviewers into the process, to be aware of positionalities, such as identification with the queer community, race, and Indigeneity. We opened the process to address the different communication dynamics that arise when author and reviewer are, or are not, known to each other. Referencing Rodriguez's (2012) writing on trans generosity, Longoria (this issue) writes about queer generosity where our presences become life-sustaining acts moving towards liberation and futurity. Generosity is a concept that all reviewers might consider, particularly when engaging with manuscripts that are personal and provocative. How do we care for those who are bringing us new ways of thinking about CYC?

Román (1998) wrote of critical generosity when considering the performances coming out of the gay community in response to AIDS in the 1980s and 1990s. Román was writing in resistance to judging such performances as though they were proscenium theatre. He argued that the standards used to assess an explicitly provocative, time-bound, life-and-death performance in response to the AIDS crisis are different than those applied to more traditional forms of theatre. While we are now in a very different time, and writing for an academic CYC journal is not the same as staging a die-in, the need for action and the need for generosity both still exist. The morning I started writing this section, I (Wolfgang) received an email from a student who had been kicked out of their home because of their sexuality; homelessness and parental rejection is still real for queer youth (Abramovich \& Shelton, 2017). The murder rate of trans people and particularly trans women of colour continues to reach new highs each year (Sonoma, 2021). These are the people that we work with as CYCPs. Yet, as Walker shows in this special issue, we rarely speak about trans, queer, two-spirit, and gender-creative folx.

We also consider generosity in how we read, and how we invite you to read, the pieces in this issue. Some of the structures and styles of the pieces included are very different from those in other academic journals. This is an area in which some of the authors pushed back at us as editors. They made compelling arguments as to why the structures they used were the right ones for their manuscripts, despite the feedback they had received. If we claim to queer and to be generous, we must start with the submissions and the people writing them. In writing about unfamiliar topics, the writing will sometimes look unfamiliar.

\section{Queer CYC Identity}

Identity is frequently present in discussions of queerness, and we are increasingly seeing the necessity of these discussions within CYC. Sometimes these are based on visible factors, such as race, ethnicity, and observable disability; at other times, they are linked to less obvious forms of 
lived experience, such as child welfare history, mental ill-health, and "invisible" disability. This extends to multiple and overlapping forms of queerness, including sexuality and gender identity, which may be more or less visible. Many, but not all, of the authors in this issue self-identify as queer, some resist this categorization, some prefer different nomenclature, and some do not explicitly state any form of identity. All of them are looking at CYC and asking questions about it. Several of the articles take an explicitly queer approach, such as playing with form or pushing the boundaries of what we think of as CYC, while others sit more obviously within CYC and can be read as residing within a traditional social science format. As noted above, most of the submissions for this special issue were from students. We find this intriguing, and perhaps revealing. We wonder, where are the queer practitioners who have left school and how do they situate themselves after leaving?

Queer and gender diverse youth continue to push researchers and practitioners to consider new practices and approaches that utilize the complexity and ever-expanding understanding of sexuality, romantic connection, gender, gender identity, and gender categories in order to refuse the simplicity of regularized identities (Mayo, 2017). Mayo (2017) has offered that "theories are research" (p. 532) and help shape how we think about ourselves and our world, providing a way to "start conversations on the shortcomings of self-understandings" (p. 532). We take the pieces in this special issue as conversation starters, many rooted in theory responding to experience, resulting in stimulating manifestations of praxis.

Disability is another identity-infused, underconsidered area of CYC addressed in this issue (see Gemar). Some of the most intriguing work on care, queering, and disability is being done by "queer crips" (Clare, 2017; Kafer, 2013; Mingus, n.d.; Piepzna-Samarasinha, 2018; Withers, 2012). A brilliant example of resisting the normal in a pedagogical context is Gemar's story of holding a class with students physically gathered in Gemar's bedroom while they taught from their bed for disability-related reasons (this issue). It is an instructive reimagining of what a queer crip CYC could be. In the hybrid that is CYC, there is much to learn about how to work from a queer, trans, and disability perspective (Vachon \& McConnell, 2018).

Disability has been, and continues to be, a contested, and complicated discourse in CYC (Erlrich, 2019; Gharabaghi, 2018; Newbury, 2018). Disability activism and research has brought awareness to the eugenic agenda embedded in much of the "care system" (Clare, 2017; Withers, 2012), a system that actively worked (and still works) to fix, cure, or remove anything considered not "fit", "healthy", or "normal" (Chapman \& Withers, 2019; Clare, 2017). CYC did not evade this historical movement and at times has been complicit in furthering an agenda based in multiple and intersecting forms of supremacy (Charles, 2015). A queered CYC is a field where normal is not the goal, or perhaps where normal is reimagined. This reimagining of the norm moves beyond disability to questioning all calls for fitting in, being respectable, behaving properly, dressing right, and being good. We say this with recognition of the complex dynamics that exist in this call. Some behaviours can lead to harming others and these need to be addressed by caring CYCPs. Further, we are not suggesting that we do not support people in understanding the implications of their 
actions and helping them to co- and self-regulate when they are having difficulty doing so. We are suggesting that we look beyond the goals of compliance and acceptability in our work with young people (as many CYCPs do). Pushing the bounds of normal requires an understanding of the institutions and systems that are implicated in projects of normalization, and the consequences of challenging them. In this regard, we look at the complex and nuanced conversations happening in BIPOC communities regarding "acceptability politics", intersectionality, and how White supremacy can lead to the murder of particular bodies who dare to question.

Violence may ensue when one does not conform. This violence can be from peers, strangers, and those in positions of authority. To fit in (to pass, to "code switch", to not be "clocked" or "read") can be a necessary skill for many queer young people navigating a world that does not always embrace difference. CYC thus has the opportunity to be a field that celebrates the differences that exist within young people. As CYCPs, we have known many young people who dress against their identity at home, only to don their identities when they are in safer spaces. This is certainly not unique to queer young people. Identity formation is important to all young people: we do harm when we restrict how people are allowed to express identity. We thus also honour their identity expressions when the young person returns home, changes clothes, asks us to interact with them differently in different contexts. We recognize that we have a responsibility to support their agency. It is not up to us to demand that they be "out", in the same way that it is not up to us to demand that they fit in.

\section{Sexuality in CYC}

Sex and sexuality are rarely celebrated in CYC, and these topics are taken up remarkably little in this special issue. Sexuality is a topic that continues to be fraught, to be considered "out of line". This taboo is certainty not confined to queer affections exclusively. There are few group homes, foster homes, or youth detention facilities where young people are formally permitted to have sex, although we wonder if these might arguably be safer spaces than the alternatives young people are forced to seek out. Opportunities to ask about sexual dangers and risks are numerous; invitations to ask about sexual joys, techniques, and positive experiences less so. Based on informal conversations with colleagues, it seems few are prepared to talk about the pleasure and processes of sex at all, let alone queer sex. Indeed, some appear to worry that their jobs would be at risk if they were "too graphic" about the hows of sex. We wonder what the impact would be if CYC were explicitly sex positive and celebrated sexuality. We think this would result in CYCPs being better prepared to support young people to develop sexual agency, practise consent, and embrace their sexuality in healthy and safe ways.

Discussion and teaching about sexuality and sex in CYC classes is also rare. One of the editorial committee members shared that she received a low grade for an early CYC paper she submitted on sexual development in young trans people on the grounds that the topic was inappropriate for a CYC developmental studies course. If we are to be training and teaching practitioners working with young people - young people who do indeed have desires, have 
sexuality, and whose sexual orientation is not just a theoretical concept but a lived experience in relationship - how can discussions about sex and sexual development be inappropriate for CYC? We see this as another example of normalization, a shadow of the moralistic values that are invoked to keep practitioners, and the children, youth, and families they work with, "in line".

With sexual orientation and gender identity (SOGI) curriculum being introduced to school districts in different regions of the country since 2014 (CBC News, 2018; Marshall, this issue; Ontario Ministry of Education, 2019), we have seen enormous pushback, discomfort, and fear from various communities, signalling the ongoing tension present when we begin to talk about sexual and gender identity for young people. While these programs have the goal of reducing discrimination and suicidal ideation for students, a protest in 2018 at the British Columbia legislature accused the SOGI curriculum of "indoctrination" and "sexualizing children" (CBC News, 2018). Similar responses were seen in reaction to the Ontario Liberal Government's 2015 health education curriculum changes (see Marshall's insightful discussion of the Ontario responses in this issue). Numerous studies have shown that queer and trans youth are more likely to experience harassment, victimization, and bullying than their cisgender heterosexual peers (e.g., Day et al., 2018; Toomey \& Russel, 2016). School-based organizations such as gender and sexuality alliances (also known as gay-straight alliances) and school policies focused on support for 2 SLGBTQ+ students have been identified as important and effective ways for improving school climates, not just for 2SLGBTQ+ but for all students (Day et al., 2018). Nevertheless, conversations about sex, sexuality, and gender continue to be a point of tension and pushback, or even of silence, in schools and in other sites of CYC practice. When we leave sex out of the conversation, we are erasing important experiences of not only identity, but also of community and relational care. We invite you to consider how you can bring into CYC celebratory stories of sex, including queer sex, that revel in joy, care, love, and passion.

While we see a move towards not only acknowledging but celebrating sexuality in CYC practice as holding great potential for change and for care, we also acknowledge the tension involved in recognizing that sexualizing and eroticizing the "other" has been used to subjugate and marginalize people based on their race, gender, or other aspects of their identity (Collins, 2020). Sex has been weaponized as a means of power and control. For some, sex has become intertwined with violence. Eroticism has similarly been used to dehumanize and fetishize identities, thus ignoring the humanity and dignity of the persons embodying eroticized identities (Mock, 2014). However, here we push back against this and consider sex and the erotic as an avenue towards care and empowerment while naming sexual and gender-based violence for what it is: violence. Nevertheless, as with many things queer, we hold this pushback with complexity, knowing that discussions about and around sex need to be conducted with respect, consent, and care for others' experiences and perspectives. 
International Journal of Child, Youth and Family Studies (2021) 12(3/4): 1-22

\section{CYC Futurity: (Un)Knowing, (Un)Doing, and (Un)Becoming}

Speculative world-making has been generative in queer theory. Through imagining what might be, the utopian project of queer futurity moves towards an envisioned future, naming and initiating the change so that it can begin to happen. We see this issue as celebrating queers and queerness, which has not always been the position taken by CYC. When discussed at all, 2SLGBTQ+ themes have often been taken up as an "issue", a "problem", or a "concern" to be "addressed", as Anderson-Nathe pointed out in his 2019 presentation at the "Child \& Youth Care in Action VI" conference hosted by the Universtiy of Victoria, British Columbia (Anderson-Nathe, 2019b). Queerness is too frequently seen through the lens of bullying, homelessness, suicidality, isolation, drug use, problematic sexual activity, or some other issue, and too frequently understood primarily as something that requires intervention. This special issue resists these positions. While we recognize the ongoing challenges faced by $2 \mathrm{SLGBTQ}+$ young people, we queer to imagine what else CYC might be beyond the pathologizing and interventions.

We imagine how we can continue the changes we are seeing in $\mathrm{CYC}$ and speculate towards the world we want to live in. Futurity is often a dialogue with our past, which guides us through the foundations it lays. One such cornerstone text of CYC literature is White's (2007) "Knowing, Doing, and Being in Context: A Praxis-Oriented Approach to Child and Youth Care". Finding its way into many CYC undergraduate and graduate course reading lists, it outlines an ethic of practice for the CYC field that emphasizes the complexity, unpredictability, and value-laden work that is CYC. We offer here a beginning towards queering this praxis model and invite a vision of CYC futurity that considers the ongoing complexity of CYC and the possibilities that may be present when we relax practice alignment by stepping "out of line". Mayo (2017) offered that "complexity, instability, and relationship have been queer practices for a long time” (p. 530). Queering CYC offers a vision of possible future practice.

\section{(Un)knowing}

As White (2007) articulated, "There are multiple ways of thinking about knowing and types of knowledge that guide CYC practitioners in their everyday work" (p. 231), noting that it is the development of specialized knowledge that defines and shapes a profession. In queering the knowing CYC, we suggest that perhaps to be out of line with this, is to step into un-knowing. If, as some scholars are starting to recognize, the "care" of CYC has been and continues to be harmful in some respects (de Finney et al., 2012, Vachon, 2020), perhaps what is needed is a move to unknowing what CYC has built itself to be, a step towards reimagining a CYC futurity that questions normalization, queers our practices, and pushes back against dangerous and damaging oppressive systems of care.

"Queer is a term that can and should be redeployed, fucked with and used in resistant and transgressive ways" (Browne \& Nash, 2010, p. 9). Ironically, the resistance and refusal of definition is how queer theory, and queer identity, is demarcated in that it knows what it is not and what it refuses (perhaps) more than it knows or wants to know exactly what it is. In refusing an 
International Journal of Child, Youth and Family Studies (2021) 12(3/4): 1-22

essentialist or core understanding of itself, it is constituted from refusal and resistance to the powerful norms it pushes against, thus becoming itself through its active protestation of being pinned down. Perhaps it is time for CYC to also consider itself in terms of what it is not (and not just as the ongoing definition that CYC is not social work!). In what ways might we fuck with CYC as a term and as a field? What does CYC need to (un)know in order to know what it is not? What does it mean to practise from a place of unknowing? We see a future through what CYC refuses to be.

\section{(Un)Doing}

White (2007) outlined the specific skills that are required for CYC work — in addition to the multiple types of knowing — that demonstrate the competencies necessary for "ethical, self-aware, responsive and accountable practice" (p. 236). While critical thinking, reflection, and analytic skills are inarguably essential to the work of $\mathrm{CYC}$, a queering of this process seeks to consider situations when CYC has felt exclusionary, been inaccessible, or been harmful and damaging. Perhaps what is needed alongside the skills and the doing of the work is an active practice of undoing harmful practices. Practitioners actively working at unknowing damaging techniques and strategies of practice are undoing the work from a place that seeks not only to do differently but to actively acknowledge, repair, and undo what has been historically harmful, oppressive, or violent in CYC. Marshall (this issue) provides a powerful exemplar of (un)doing from the position of a self-identified "White, straight, cis-gendered, and non-disabled settler with European colonial roots", through an autoethnographic research process looking at her own heterocisnormativity.

\section{(Un)Becoming}

Queer theory and methodology are often associated with explorations of differences and the resistance and contestation of normalizing discourses, strict categories, and rigid boundaries, while emphasizing the fluidity of spaces and the process of "becoming" (Browne, 2008; Haritaworn, 2008). Heckert (2010) drew on Deleuze and Guattari (1994) to conceptualize becoming as embracing 'learning to 'be comfortable with uncertainty' (Chödrön, 2002), a process which is never finished, accomplished, achieved" (p. 42) but is always in process, "experienced in the present and in presence" (p. 43).

White (2007) introduced the idea of being in CYC practice by emphasizing the importance of the relational qualities that define CYC work. White offered that the work of CYC is about " being with' as opposed to "doing to" " and that the issue of "knowing how to be" is a key element of CYC praxis (p. 239). Here, through queering CYC, we offer that perhaps the question again is not a "knowing how to be" but starting from a place of knowing "how not to be", and at times actively (un)knowing how to be. (Un)becoming suggests stepping out of line with what is expected; queering might well be seen as an unbecoming position, given CYCs historical focus on acceptance. We embrace this refusal to accede to our accepted role and step towards a vision of CYCPs as embodying an (un)becoming (through our unbecoming bodies) that allows for an 
imperfect, but active, process of practising CYC. In the dissolution through (un)becoming, we see the possibility of a new emerging.

Queering CYC is a speculative project of imagining and then manifesting (Alexander, 2018). As Ansloos et al. write in this issue:

Indigenous queer futures are rich with political imagination: when queer Indigenous activists choose to share their stories, to listen well is to listen for the ways political imagination takes shape in all aspects of life as they imagine daily resistance to the colonial present through reassertion and reimagining of Indigenous life ways and futures.

Reading this special issue is an act of listening, imagining what can (un)become, and heeding the calls to care. In listening to the contributors of this special issue we are invited towards new ways of being CYCPs and of understanding CYC. Queering CYC, then, is a project of futurity, of "cruising utopia", as Muñoz (2019) famously wrote. More than a review of the present moment, this issue seeks to imagine the future and then (un)become. 
International Journal of Child, Youth and Family Studies (2021) 12(3/4): 1-22

\section{References}

Abramovich, A., \& Shelton, J. (Eds.). (2017). Where am I going to go? Intersectional approaches to ending LGBTQ2S youth homelessness in Canada \& the U.S. Canadian Observatory on Homelessness Press.

Alexander, B. K. (2018). Queer/quare theory: Worldmaking and methodologies. In N. K. Denzin $\&$ Y. S. Lincoln (Eds.), The SAGE handbook of qualitative research (5 ${ }^{\text {th }}$ ed.; pp. 275-307). Sage Publications.

Amponsah, P., \& Stephen, J. (2020). Developing a practice of African-centred solidarity in child and youth care. International Journal of Child, Youth and Family Studies, 11(2), 6-24. doi:10.18357/ijcyfs112202019516

Anderson-Nathe, B. (2019a). Queering gender and sexuality in child and youth care. In K. Gharabaghi \& G. Charles, (Eds.), Child and youth care across sectors: Canadian perspectives (Vol. 1; pp. 157-172. Canadian Scholars.

Anderson-Nathe, B. (2019b, April 25-27). Queer young people's coming of age experiences [Paper presentation]. Child \& Youth Care in Action VI Conference, University of Victoria, Victoria, British Columbia.

Anglin, J. (2001). Child and youth care: A unique profession. CYC-Online, 35. http://www.cycnet.org/cyc-online/cycol-1201-anglin.html

Ahmed, S. (2006). Queer phenomenology. Duke University Press.

Ball, M. (2016). Criminology and queer theory: Dangerous bedfellows? Palgrave Macmillan. doi:10.1057/978-1-137-45328-0

Belcourt, B. R. (2020). A history of my brief body. Penguin Random House Canada.

Barker, M.-J., \& Scheele, J. (2016) Queer: A graphic history. Icon Books.

Batasar-Johnie, S. (2017). A response to "Why are we so White": A West-Indian/Indo-Caribbean Canadian practitioner. CYC-Online, 221, 5-9. https://www.cyc-net.org/cyc-online/jul2017.pdf

Browne, K. (2008). Selling my queer soul or queerying quantitative research? Sociological Research Online, 13(1), 200-214. doi:10.5153/sro.1635

Browne, K., \& Nash, C. J. (2010). Queer methods and methodologies: An introduction. In, K. Browne \& C. J. Nash (Eds.), Queer methods and methodologies: Intersecting queer theories and social science research (pp. 1-24). Routledge. 
International Journal of Child, Youth and Family Studies (2021) 12(3/4): 1-22

CBC News. (2018, September 29). Protesters for and against school SOGI policy rally at B.C. legislature. https://www.cbc.ca/news/canada/british-columbia/protesters-for-and-againstschool-sogi-policy-rally-at-b-c-legislature-1.4844400

Chandler, D., \& Munday, R. (2011). Queer theory. In A Dictionary of Media and Communication. Oxford University Press.

Chapman, C., \& Withers, A. J. (2019). A violent history of benevolence: Interlocking oppression in the more economies of social working. University of Toronto Press.

Charles, G. (2015). Doomed to repeat it: The selective and collective ignorance of the shadowy historical foundations of child and youth care. CYC-Online, 200, 52-58. https://cycnet.org/cyc-online/oct2015.pdf

Cherry, S., \& Vachon, W. (2020). Self-Disclosure by child and youth care practitioners in the workplace. CYC-Online, 258, 58-68. https://cyc-net.org/cyc-online/oct2020.pdf

Chödrön, P. (2002). Comfortable with uncertainty: 108 teachings on cultivating fearlessness and compassion. Shambhala.

Chung, I. (2017) From a young person's perspective: Towards a better residential care system for youth. CYC-Online, 218, 11-19. https://cyc-net.org/cyc-online/apr2017.pdf

Clare, E. (2017). Brilliant imperfection: Grappling with cure. Duke University Press.

Clifton, D. (2020, November 12). At least 350 transgender peope lhave been killed globally in 2020. Them. https:/www.them.us/story/at-least-350-transgender-people-killed-globally-in$\underline{2020}$

Collins, P. H. (2020). Prisons for our bodies, closets for our minds: Racism, heterosexism, and Black sexuality. In J. J. Dean and N. L. Fischer (Eds.), Routledge International Handbook of Heterosexualities Studies (pp. 217-238). Routledge.

Daniel, B. (2018). Racism is a thing! Re-examination of the concepts of care and relational practice in the preparation of child and youth care practitioners. Relational Child and Youth Care Practice, 31(3), 31-41.

Day, J. K., Perez-Brumer, A., \& Russell, S. T. (2018). Safe schools? Transgender youth's school experiences and perceptions of school climate. Journal of Youth and Adolescence, 47, 17311742. doi:10.1007/s10964-018-0866-X

de Finney, S., Dean, M., Loiselle, E., \& Saraceno, J. (2011). All children are equal, but some are more equal than others: Minoritization, structural inequities, and social justice praxis in residential care. International Journal of Child, Youth and Family Studies, 2(3/4), 361-384. doi:10.18357/ijcyfs23/420117756 
International Journal of Child, Youth and Family Studies (2021) 12(3/4): 1-22

de Finney, S., Little, J. C., Skott-Myhre, H., \& Gharabaghi, K. (2012). Conversations on conversing in child and youth care. International Journal of Child, Youth and Family Studies, 3(2-3), 128-145. doi:10.18357/ijcyfs32-3201210862

de Finney, S., Chadwick, C., Adams, C., Moreno, S., Scott, A., \& Sam, S-R. (2020). Being Indigenous is not a risk factor: A Sisters Rising story of resurgence and sovereignty. In K. Gharabaghi \& G. Charles, (Eds.), Child and youth care across sectors: Canadian perspectives (Vol. 2, pp. 6-23). Canadian Scholars.

Deleuze, G., \& Guattari, F. (1994). What is philosophy? (J. Tomlinson \& G. Birchill, Trans.). Columbia University Press.

Driskell, Q. L. (2016). Asegi stories: Cherokee queer and two-spirit memory. University of Arizona Press.

Duberman, M. (1993). Stonewall. Plume.

Ellison, T., Green, K. M., Richardson, M., \& Snorton, C. R. (2017). We got issues: Toward a Black trans*/studies. TSQ: Transgender Studies Quarterly, 4(2), 162-169. doi:10.1215/23289252-3814949

Erlich, S. (2019). Child and youth care practice in the context of deaf communities. In K. Gharabaghi \& G. Charles, (Eds.), Child and youth care across sectors: Canadian perspectives (Vol. 1; pp. 173-191). Canadian Scholars.

Garfat, T. (2012). Discovering truth in their experiences: Practice-based evidence from youth and their families. In T. Garfat \& L. C. Fulcher (Eds.), Child and youth care in practice (pp. 44-48). The CYC-Net Press. http://press.cyc-net.org/samples/CYCiP.pdf

Garfat, T., Freeman, J., Gharabaghi, K., \& Fulcher, L. (2018). Characteristics of a relational child and youth care approach revisited. CYC-Online, 236, 7-45. https://cyc-net.org/cyconline/oct2018.pdf

Garfat, T., \& Fulcher, L. (2012). Child and youth care in practice. The CYC-Net Press. http://press.cyc-net.org/samples/CYCiP.pdf

Gharabaghi, K. (2018). Child and youth care, disability and some cautions. CYC-Online, 237, 118-122. https://cyc-net.org/cyc-online/nov2018.pdf

Ghaziani, A., \& Brim, M. (2019). Imagining queer methods. New York University Press.

Haritaworn, J. (2008). Shifting positionalities: Empirical reflections on a queer/trans of colour methodology. Sociological Research Online, 13(1), 162-173. doi:10.5153/sro.1631 
International Journal of Child, Youth and Family Studies (2021) 12(3/4): 1-22

Heckert, J. (2010). Intimacy with strangers/intimacy with self: Queer experiences of social research 1. In K. Browne \& C. J. Nash (Eds.), Queer methods and methodologies: Intersecting queer theories and social science research (pp. 41-54). Routledge. doi: $10.4324 / 9781315603223-3$

Hillman, M., Dellebuur O'Connor, K., \& White, J. (2020). Reckoning with our privileges in the CYC classroom: Decentring Whiteness, enacting decolonial pedagogies, and teaching for social justice. International Journal of Child, Youth and Family Studies, 11(2), 40-60. doi:10.18357/ijcyfs112202019518

Hyder, S., Marshall, N., \& Hillman, M. (2019). Politicizing CYC: An integral aspect of relational practice. Relational Child and Youth Care Practice, 32(4), 90-106. https://rcycp.com/docs/RCYCP_Vol32-4_sample.pdf

Ineese-Nash, N. (2020). Mino-bimaadiziwin wiidookodaadiwag (Helping each other through the good life): Implications for research and practice with Indigenous communities. In K. Gharabaghi \& G. Charles (Eds.), Child and Youth Care across Sectors (Vol. 2, Ch. 2). Candian Scholars Press.

Jagose, A. (1996). Queer theory: An introduction. New York University Press.

Johnson, E. P., \& Rivera-Severa, R. H. (2016). Blacktino queer performance. Duke University Press.

Kafer, A. (2013). Feminist, queer, crip. Indiana University Press.

Keegan, C. M. (2020) Against queer theory. TSQ: Transgender Studies Quarterly, 7(3), 349353. doi:10.1215/23289252-8552978

Kouri, S. (2014). Conceptualizing self, identity, and subjectivity: Engagements with theories and theorists in child and youth care [Master's thesis, University of Victoria]. https://dspace.library.uvic.ca/handle/1828/5611

Lather, P. (2009). Getting lost: Social science and/as philosophy [2007 Kneller Lecture, American Educational Studies Association]. Educational Studies, 45, 342-357. $\underline{\text { doi: } 10.1080 / 00131940903066248}$

Little, J. N. (2011). Articulating a child and youth care philosophy: Beyond binary concepts. In A. Pence \& J. White (Eds.), Child and youth care: Critical perspectives on pedagogy, practice and policy (pp. 3-18). University of British Columbia Press.

MacKenzie, K. (2019). Integrating fluid, responsive, and embodied ethics: Unsettling the praxis of White settler CYC practioners [Master's thesis, University of Victoria]. https://dspace.library.uvic.ca/handle/1828/11203 
International Journal of Child, Youth and Family Studies (2021) 12(3/4): 1-22

Marshall, N. (2019). Why should we care? Reflecting on child and youth care practice for, about, and with autistic young people. In K. Gharabaghi \& G. Charles (Eds.), Child and youth care across sectors: Canadian perspectives (Vol. 1; 136-156). Canadian Scholars.

May, T. (2005). To change the world, to celebrate life: Merleau-Ponty and Foucault on the body. Philosophy \& Social Criticism, 31(5-6), 517-531. doi:10.1177/0191453705055487

Mayo, C. (2017). Queer and trans youth, relational subjectivity, and uncertain possibilities: Challenging research in complicated contexts. Educational Researcher, 46(9), 530-538. doi:10.3102/0013189X17738737

McCready, L. T. (2013). Conclusion to the special issue: Queer of color analysis: Interruptions and pedagogic possibilities. Curriculum Inquiry 43(4), 512-522. doi:10.1111/curi.12024

Mingus, M. Leaving evidence [Blog]. https://leavingevidence.wordpress.com/ about-2/

Mock, J. (2014). Redefining realness: My path to womanhood, identity, love \& so much more. Atria Books.

Muñoz, J. E. (2019). Cruising utopia, 10th anniversary edition: The then and there of queer futurity. New York University Press.

Munroe, T. (2016). From college to university: What I learned navigating the child and youth care curriculum. Relational Child and Youth Care Practice, 29(3), 91-100.

https://rcycp.com/docs/RCYCP_Vol29-3.pdf

Newbury, J. (2018). Child and youth care: Disability matters [Editorial]. CYC-Online, 237, 3-8. https://cyc-net.org/cyc-online/nov2018.pdf

Ontario Ministry of Education. (2019). The Ontario curriculum: Grades 1-8. Health and physical education. http://www.edu.gov.on.ca/eng/curriculum/elementary/2019-healthphysical-education-grades-1 to8.pdf

Pico, T. (2019). Feed. Tin House Books.

Piepzna-Samarasinha, L. L. (2018). Care work: Dreaming disability justice. Arsenal Pulp Press.

Puar, J. K. (2017). The right to maim: Debility, capacity, disability. Duke University Press.

Rodriguez, N. (2012). Queer imaginative bodies and the politics and pedagogy of trans generosity: The case of Gender Rebel. In J. C. Landreau \& N. Rodriguez (Eds.), Queer masculinities: A critical reader in education (pp. 267-288). Springer. doi:10.1007/978-94$\underline{007-2552-2 \_16}$

Román, D. (1998). Acts of intervention: Performance, gay culture, and AIDS. Indiana University Press. 
International Journal of Child, Youth and Family Studies (2021) 12(3/4): 1-22

Simpson, L. B. (2020). Noopiming: The cure for White ladies. House of Anansi Press.

Skott-Myhre, K., Kouri, S., and Skott-Myhre, H. (2020). De-settlering ourselves: Conference reflections. International Journal of Child, Youth and Family Studies, 11(2): 94-110. doi:10.18357/ijcyfs112202019521

Skott-Myhre, K., \& Skott-Myhre, H. A. (2012). Theorizing and applying child and youth care practice as politics of care. In T. Garfat \& L. C. Fulcher (Eds.), Child and youth care in practice (pp. 169-185). The CYC-Net Press. http://press.cyc-net.org/samples/CYCiP.pdf

Stuart, C. (2013). Foundations of child and youth care. Kendall Hunt.

Sonoma, S. (2021, January 7). 44 trans people killed in 2020, marking worst year on record for transphobic violence. Them. https://www.them.us/story/44-trans-people-killed-2020-worstyear-for-transphobic-violence

Stryker, S., \& Bettcher, T. M. (2016). Introduction: Trans/feminisms. TSQ: Transgender Studies Quarterly, 3(1-2), 5-14. doi:10.1215/23289252-3334127

Sullivan, N. (2003). A critical introduction to queer theory. Edinburgh University Press

Toomey, R. B., \& Russell, S. T. (2016). The role of sexual orientation in school-based victimization: A meta-analysis. Youth \& Society, 48, 176-201.

doi:10.1177/0044118X13483778

Vachon, W. (2021). CYC aesthetics and the beauty of relational inquiry. In H. Modlin, J. Freeman, C. Gaitens, \& T. Garfat (Eds.), Relational youth care in action (pp. 117-127). The CYC-Net Press. http://press.cyc-net.org/samples/RCYCP InAction.pdf

Vachon, W. (2020). Queering child and youth care. International Journal of Child, Youth and Family Studies, 11(2), 61-81. doi:10.18357/ijcyfs112202019519

Vachon, W., \& McConnell, T. (2018). Allies, not accomplices: What youth work can learn from trans and disability movements. In P. Alldred, F. Cullen, K. Edwards, \& D. Fusco (Eds.), The SAGE handbook of youth work practice (pp. 426-439). SAGE Publications. doi:10.4135/9781526416438.n32

Withers, A. J. (2012). Disability politics and theory. Fernwood Publishing

White, J. (2007). Knowing, doing, and being in context: A praxis-oriented approach to child and youth care. Child \& Youth Care Forum, 36(5), 225-244. doi:10.1007/s10566-007-9043-1

White, J. (2015). An ethos for the times: Difference, imagination, and the unknown future in child and youth care. International Journal of Child, Youth and Family Studies, 6(4), 498515. doi:10.18357/ijcyfs.64201514285

Whitehead, J. (2018). Jonny Appleseed. Arsenal Pulp Press. 